\title{
KONTRIBUSI PRAKTEK KERJA INDUSTRI DAN MOTIVASI BELAJAR TERHADAP SIKAP WIRAUSAHA
}

\author{
Anramus \\ SMK Negeri 1 Tembilahan Hulu \\ J1. Propinsi Pulau Palas, Indragiri Hilir 29251
}

\begin{abstract}
Abstrak: Penelitian ini bertujuan untuk mengetahui seberapa besar kontribusi praktek kerja industri dan motivasi belajar siswa terhadap sikap berwirausaha. Penelitian dilakukan pada siswa SMK Negeri 1 Tembilahan Hulu dengan sampel sebanyak 38 siswa dan pengumpulan data menggunakan angket dan dokumentasi. Hasil penelitian diperoleh bahwa hasil praktek kerja industri dan motivasi siswa mempunyai kontribusi yang tinggi terhadap sikap wirausaha siswa. Kesimpulan dari penelitian ini yaitu untuk meningkatkan kualitas lulusan SMK sekolah harus menempatkan siswa pada industri yang tepat dan relevan. Selain itu, memberikan pemahaman terhadap siswa agar memacu motivasi siswa untuk memiliki sikap wirausaha dan mampu menghadapi berbagai tantangan dalam dunia kerja dan kehidupan.
\end{abstract}

Kata kunci: mutu lulusan, praktek kerja industri, wirausaha.

\begin{abstract}
This study aims to determine how much the contributions industry practices and student motivation on attitudes to entrepreneurship. The study was conducted on students of SMK Negeri 1 Tembilahan Hulu with a sample of 38 students and collecting data using questionnaires and documentation. The result showed that the industry practices and student motivation has a higher contribution to the students' entrepreneurial attitude. The conclusion of this research is to improve the quality of graduates of vocational schools should place students in appropriate and relevant industries. In addition, provide an understanding of student motivation in order to encourage students to have an entrepreneurial attitude and be able confront the challenges in the world of work and life.
\end{abstract}

Keywords: quality of graduates, industry practices, entrepreneurship.

\section{PENDAHULUAN}

Konsep pendidikan pada hakikatnya merupakan proses pembentukan pribadi agar diperoleh kemampuan yang berlebih dari sebelumnya. Sasaran pembentukannya menyangkut seluruh aspek, antara lain: intelektual, sikap, dan keterampilan. Hal tersebut terkait pula dengan pernyataan tentang SK. Mendikbud No.0490/U/1999, yaitu: "Menyiapkan siswa untuk melanjutkan ke jenjang yang lebih tinggi sehingga dapat mengembangkan diri sejalan dengan pengembangan ilmu pengetahuan dan teknologi dan, untuk memasuki dunia kerja yang lebih profesional".

Berdasarkan pengamatan dan fenomena yang ada di lapangan, tamatan SMK diperoleh gambaran kurang memiliki sikap berwirausaha. Siswa SMK 
sebenarnya sudah diajarkan tentang pendidikan berwirausaha disekolah, hal ini terlihat belum merupakan dorongan untuk mereka berwirausaha.

Sesuai dengan tekad Sekolah Menengah Kejuruan (SMK) untuk menghasilkan lulusan yang berkualitas, diimbangi dengan adanya upaya untuk meningkatkan motivasi belajar siswanya. Sekolah Menegah Kejuruan (SMK) berupaya berperan aktif dalam menyiapkan sumberdaya manusia terdidik yang mampu menghadapi berbagai tantangan kehidupan baik lokal, regional, nasional maupun internasional. Siswa tidak cukup hanya menguasai teori-teori, tetapi juga mau dan mampu menerapkannya dalam kehidupan sosialnya, tidak hanya mampu menerapkan ilmu yang diperoleh di bangku sekolah, tetapi juga mampu memecahkan berbagai persoalan yang dihadapi dalam kehidupan sehari-hari. Menurut Suryadi (2005), bahwa tingkat semangat berwirausaha siswa tingkat SLTA di ndonesia sebesar $15,30 \%$, artinya tingkat minat kewirausahaan siswa sekolah, termasuk siswa SMK masih perlu ditingkatkan. Sikap wirausaha lahir dari adanya dorongan yang kuat pada diri individu. Hal ini seperti dikatakan Ropke yang mengatakan bahwa "kemampuan, motivasi, lingkungan dan hak milik adalah faktor penentu sikap/perilaku kewirausahaan" (Ropke 1995: 49).

Hal yang mendasar dalam proses belajar mengajar salah satunya adalah sebuah metode pembelajaran yang digunakan oleh seorang pendidik. Ketepatan dalam menyampaikan materi pembelajaran dengan metode pembelajaran yang benar akan mempermudah dan mempercepat proses penyampain ilmu kepada anak didik, maka sebagai pengajar perlu kita memperhatikan metode belajar yang kita gunakan dalam pembelajaran apakah sesuai dengan standar kompetensi saat ini.

Metode pembelajaran disesuaikan dengan materi, seperti Bidang Studi yang terdapat di SMK yang lebih banyak menerapkan pembelajaran yang bersifat praktek, metode yang akan diterapkan adalah metode praktikum, bukan berarti metode lain tidak kita pergunakan, metode ceramah sangat perlu yang waktunya dialokasi sekian menit untuk memberi petunjuk, aba-aba, dan arahan. Kemudian memungkinkan mempergunakan metode diskusi, karena dari hasil praktikum siswa memerlukan diskusi kelompok untuk memecah masalah/problem yang mereka hadapi. 
Metode pembelajaran disesuaikan dengan materi, seperti Bidang Studi yang terdapat di SMK yang lebih banyak menerapkan pembelajaran yang bersifat praktek, metode yang akan diterapkan adalah metode praktikum, bukan berarti metode lain tidak kita pergunakan, metode ceramah sangat perlu yang waktunya dialokasi sekian menit untuk memberi petunjuk, aba-aba, dan arahan. Kemudian memungkinkan mempergunakan metode diskusi, karena dari hasil praktikum siswa memerlukan diskusi kelompok untuk memecah masalah/problem yang mereka hadapai.

Praktek kerja industri (PRAKERIN) merupakan salah satu penerapan metode mengajar dalam bentuk kerja lapangan, siswa di tempatkan langsung di dunia usaha dan dunia industri. Pelaksanaan Prakerin merupakan bagian dari Pendidikan Sistem Ganda yang merupakan inovasi pada program SMK dimana peserta didik melakukan praktek kerja (magang) di perusahaan atau industri yang merupakan bagian integral dari proses pendidikan dan pelatihan di SMK.

Prakerin dalam rangka pelaksanaan Pendidikan Sistim Ganda (PSG) pada Sekolah Menengah Kejuruan (SMK) didasarkan atas ketentuan yang tertuang dalam Kepmendikbud No. 323/U/1993, tentang Penyelenggaraan PSG pada SMK. Praktek kerja industri merupakan salah satu model penyelenggaraan pendidikan profesional yang memadukan secara sistematis dan sinkronisasi antara pendidikan di sekolah dan penguasaan keahlian atau keterampilan yang diperoleh melalui bekerja langsung di dunia kerja dan dunia industri untuk mencapai suatu tingkat keahlian yang cukup profesional sesuai dengan program keahlian dan dan yang diharapkan dalam profil kemampuan lulusan SMK (Panduan Prakerin, 2002:5).

Sardiman (2011:73) mengemukakan bahwa motivasi adalah perubahan energi dalam diri seseorang yang ditandai dengan munculnya "feeling" dan didahului dengan tanggapan terhadap adanya tujuan. Peran motivasi dalam kegiatan belajar ditentukan oleh keseriusan dalam mengikuti pelajaran, yang jelas didorong oleh motivasi dari luar dan dari dalam diri siswa itu sendiri. Disini guru sebagai motivator mempunyai peran yang cukup besar dalam meningkatkan motivasi kepada siswa.

Pembentukan sikap kewirausahaan dapat terlihat dalam kehidupan seharihari seorang siswa. Sikap dan perilaku seseorang cenderung terbentuk oleh faktor- 
faktor pengalaman pribadi, kebudayaan, orang lain yang dianggap penting, media massa, Institusi atau lembaga pendidikan dan agama, dan faktor emosional. Banyak ahli yang mengemukakan karakteristik seorang wirausaha, berikut ini ciri-ciri dan watak wirausaha.

Tabel 1. Ciri dan Watak Wirausaha

\begin{tabular}{|c|c|c|}
\hline No & Ciri & Watak \\
\hline 1 & Percaya diri & $\begin{array}{l}\text { Keyakinan, } \\
\text { individualistis, dan optimisme. }\end{array}$ \\
\hline 2 & $\begin{array}{l}\text { Berorientasi pada tugas } \\
\text { dan hasil }\end{array}$ & $\begin{array}{l}\text { Kebutuhan untuk berprestasi, berorientasi } \\
\text { laba, ketekunan dan ketabahan, tekad kerja } \\
\text { keras, mempunyai dorongan kuat, } \\
\text { energetik dan inisiatif }\end{array}$ \\
\hline 3 & Pengambilan resiko & $\begin{array}{l}\text { Kemampuan untuk mengambil resiko } \\
\text { yang wajar dan suka tantangan }\end{array}$ \\
\hline 4 & Kepemimpinan & $\begin{array}{l}\text { Perilaku sebagai pemimpin, bergaul } \\
\text { dengan orang lain, menanggapi saran- } \\
\text { saran dan kritik }\end{array}$ \\
\hline 5 & Keorisinilan & Keorisinilan \\
\hline 6 & $\begin{array}{l}\text { Berorientasi ke masa } \\
\text { depan }\end{array}$ & Pandangan ke depan, perspektif \\
\hline
\end{tabular}

Sumber: Suryana (2003:14)

\section{METODE}

Metode penelitian yang digunakan adalah metode survey dengan menggunakan instrument penelitian angket dan panduan observasi. Populasi dalam penelitian ini adalah siswa SMK N 1 Tembilahan Hulu yang telah mengikuti praktek kerja industri (kelas XI) di dunia usaha dan dunia industri. Sampel yang diambil adalah $50 \%$ dari 75 adalah 37,5 maka dibulatkan menjadi 38 orang siswa. Semua responden diberikan pertanyaan dan pernyataan yang terkait dengan prakerin, motivasi dan wirausaha. Semua responden diminta untuk mengisi angket yang telah disediakan dan diobservasi yang terkait dengan fokus penelitian. 


\section{HASIL PENELITIAN DAN PEMBAHASAN}

Hasil analisis deskripsi data menunjukkan bahwa dari 79,84\% responden menyatakan prakerin memberikan manfaat dan memiliki kontribusi yang tinggi terhadap sikap wirausaha. Persamaan regresi diperoleh, yaitu: $Y=46,977+0,718$ $\mathrm{X} 1$. Hal ini menunjukkan bahwa variabel prakerin $\left(\mathrm{X}_{1}\right)$ akan mempengaruhi atau berkontribusi terhadap sikap wirausaha dengan laju peningkatan sebesar 0,718. Hal ini menunjukkan bawah prakerin memiliki nilai pengaruh yang liner terhadap sikap wirausaha. Sedangkan derajat hubungan antara prakerin dan sikap wirausaha diperoleh nilai koefisien korelasi sebesar 0,454 . Kontribusi prakterin terhadap sikap wirausaha siswa ditunjukkan oleh nilai koefisien determinasinya, yaitu 0,206. Hal ini berarti bahwa hasil atau manfaat prakerin memberikan sumbangan terhadap sikap wirausaha siswa sebesar 20,6\%. Nilai tersebut tergolong tinggi sehingga perlu dipertahankan dan perlu dikembangkan terus. Kondisi tersebut juga dipengaruhi oleh faktor lain, yang dalam penelitian ini tidak dibahas. Faktor lain tersebut perlu dianalisis dan ditelusuri agar faktor tersebut ikut berkontribusi terhadap sikap wirausaha siswa.

Hasil analisis deskripsi data mengenai Motivasi Belajar terungkap bahwa $87,13 \%$ responden menyatakan besaran motivasi belajar mempengaruhi sikap kewirusahaan siswa. Nilai tersebut tergolong dalam kategori tinggi, Persamaan regresi yang diperoleh dari hasil perhitungan dan pengujian hipótesis, yaitu: $\mathrm{Y}=$ $21,948+1,041 \mathrm{X}_{2}$. Hal ini menunjukkan bahwa nilai variabel motivasi belajar akan mempengaruhi sikap wirausaha siswa. Nilai tersebut menunjukkan secara linier bahwa setiap peningkatan nilai motivasi belajar diikuti juga oleh nilai sikap wirausaha siswa. Berdasarkan hasil pengujian nilai korelasi menunjukkan bawah nilai koefisien korelasi sebesar 0,622, artinya terdapat hubungan yang tinggi antara motivasi belajar dengan sikap wirausaha siswa. Apabila dilihat pada nilai kontribusi motivasi belajar terhadap sikap wirausaha siswa mempunyai nilai koefisien determinasinya adalah 0,387. Nilai kontribusi tersebut menunjukkan bahwa motivasi belajar memberikan sumbangan dan pengaruh yang besar dalam membentuk sikap kewirausahaan siswa. Dengan demikian, sikap tersebut harus terus dibina dan dikembangkan agar siswa memiliki sikap kewirausahaan yang 
terus meningkat dan mantap. Hal tersebut tentu saja dipengaruhi oleh faktor lain yang nilainya lebih besar dari angka tersebut. Namun angka tersebut terdiri dari beberapa faktor yang tidak diteliti dalam penleitian ini. Hal tersebut menunjukkan bahwa faktor pembentuk sikap wirausaha siswa tidak hanya motivasi belajar, namun banyak faktor yang mempengaruhinya yang perlu diteliti lagi agar lebih lengkap.

Hasil analisis deskripsi data mengenai sikap wirausaha terungkap bahwa sebanyak $84,49 \%$ responden menyatakan besarnya sikap wirausaha dipengaruhi oleh motivasi dan prakerin. Nilai ini apabila dilihat dari pengelompokkan indeks korelasi termasuk ke dalam kategori tinggi. Persamaan regresi diperoleh yang didasarkan pada hasil pengujian hipótesis, yaitu: $\mathrm{Y}=20,828+0,202 \mathrm{X}_{1}+0,905$ $\mathrm{X}_{2}$. Hal ini menunjukkan bahwa prakerin dan motivasi belajar masing-masing memberikan pengaruh yng berbeda terhadap pembentukansikap wirausaha siswa. Variabel prakerin dan motivasi belajar akan memberikan pengaruh dan peningkatan sebesar 0,202 dan 0,905 terhadap pembentukan sikap wirausaha siswa. Berdasarkan hasil pengujian hipotesis diperoleh nilai koefisien korelasi sebesar 0,632, hal itu mengindikasikanbahwa ketiga variabel tersebut menunjukkan adanya saling keterhubungan dan keterpengaruhan antara satu sama lain. Merujuk pada nilai koefisien determinasi, yaitu 0,40, yang menunjukkan bahwa sikap wirausaha siswa turut ditentukan oleh faktor prakerin dan motivasi belajar siswa. Nilai tersebut juga dapat dikatakan sebuah sumbangan atau kontribusi prakerin dan motivasi belajar siswa terhadap pembentukan sikap atau karakter kewirausahaan siswa. Namun tidak dapat dihindari ada faktor lain yang nilainya justru lebih tinggi dari kedua variabel tersebut. Faktor di luar kedua variabel tersebut jgua turut berkontribusi, namun dalam penelitian ini tidak dibahas secara mendalam. Hal tersebut merupakan salah satu kelemahan dalam penelitian ini. Dengan demikian, masih terbuka untuk diteliti faktor-faktor tersebut. 


\section{KESIMPULAN}

Kesimpulkan dari hasil penelitian ini bahwa sebagian besar siswa menyatakan bahwa praktek kerja industri, motivasi belajar dan sikap wirausaha yang cenderung tinggi. Pelaksanaan prakerin dapat mendorong meningkatnya motivasi siwa dan pada akhirnya akan mempengaruhi pembentkan dan dapat meningkatkan sikap berwirausaha. Kontribusi positif juga diberikan antara motivasi belajar dengan sikap wirausaha. Semakin besar motivasi yang dimiliki siswa dalam proses belajar mengajar maka akan semakin tinggi sikap wirausahanya. Kenaikan satu skor nilai motivasi belajar siswa akan merubah sikap wirausaha ke arah yang lebih baik. Dengan demikian dapat dikatakan bahwa, semakin besar kontribusi yang dilakukan siwa dalam praktek kerja industri, dalam hal ini siwa yang semakin baik dalam melakukan praktek kerja industri maka sikap wirausaha setelah lulus sekolah akan semakin besar.

\section{DAFTAR PUSTAKA}

Depdikbud. 1995. Kurikulum Sekolah Menengah Kejuruan. Jakarta: Depdikbud

Dikmenjur. 2002. Pelaksanaan Prakerin. Jakarta : Direktorat Pembinaan Sekolah Menengah Kejuruan, Depdiknas

Sardiman, A.M (2007) Ilmu Pendidikan, Bandung: Remaja Karya

Suryana. (2003). Kewirausahaan. Pedoman Praktis, Kiat dan Proses Menuju Sukses. Jakarta: Salemba Empat 